\title{
Paweł Jaworski
}

Wrocław

\section{Szwedzki oddział „wileński" - niezrealizowana ekspedycja rozjemcza w 1920/1921 roku}

\begin{abstract}
Abstrakt: Celem niniejszego tekstu jest zaprezentowanie problemu ze szwedzkiej perspektywy, z uwzględnieniem celów polityki zagranicznej neutralnej Szwecji, jej aktywności w Lidze Narodów oraz stosunku do sytuacji po drugiej stronie Bałtyku. Spór polsko-litewski obserwowano w Sztokholmie z uwagą, ale nie angażowano się w jego rozwiązanie. Dopiero w listopadzie 1920 r. Liga Narodów zwróciła się m.in. do Szwecji o wysłanie do Wilna oddziału wojskowego, który miałby zabezpieczyć obszar planowanego plebiscytu.
\end{abstract}

Słow a klucz owe: Wilno, Liga Narodów, Szwecja, plebiscyt, państwa skandynawskie.

Abstract: The purpose of the article is to present the problem as seen from the Swedish perspective, with due regard to foreign policy aims of neutral Sweden, its activity in the League of Nations, and its attitude towards the situation on the other side of the Baltic Sea. The Polish-Lithuanian conflict was carefully observed from Stockholm, but without any Swedish engagement. Only in November of 1920 the League of Nations asked Sweden, among other countries, to send to Vilnius a military unit to protect the planned plebiscite area.

Keyw or ds: Vilnius, League of Nations, Sweden, plebiscite, Scandinavian states.

Spór polsko-litewski o Wileńszczyznę w latach 1918-1923 ma już bogatą literaturę. Przede wszystkim Piotr Łossowski w swych opracowaniach, publikowanych od wielu lat, objaśnia kompleksowo problemy związane z tym zagadnieniem, w tym genezę konfliktu. W pierwszej kolejności chodziło o brak porozumienia obu stron, wynikający z odmiennych koncepcji rozwoju własnej państwowości: Polska planowała odrodzenie przedrozbiorowej unii obu krajów, Litwa natomiast wolała rozwijać się samodzielnie w granicach 
wykraczajacych poza jej obszar etniczny ${ }^{1}$. Znane jest też zaangażowanie Ligi Narodów w całą sprawę, łącznie z propozycja przeprowadzenia na spornym obszarze plebiscytu pod ochrona sił międzynarodowych². Słabo poznany watek stanowi natomiast kwestia organizacji oddziałów z różnych krajów, które miały wziąć udział w (ostatecznie niedoszłej do skutku) wyprawie do Wilna. Przed 25 laty udział norweski w przygotowaniach do tej pokojowej misji przedstawił Tom Kristiansen ${ }^{3}$. Kilka lat temu na łamach „Dziejów Najnowszych" o duńskim oddziale stworzonym specjalnie na plebiscyt na pograniczu polsko-litewskim pisali historycy polscy ze Szczecina ${ }^{4}$. Celem niniejszego tekstu jest zaprezentowanie problemu ze szwedzkiej perspektywy ${ }^{5}$.

Szwecja wraz z zakończeniem I wojny światowej, podobnie jak pozostałe kraje skandynawskie, stanęła przed dylematem, jaka strategię obrać w polityce zagranicznej. Czy trzymać się kurczowo neutralności i izolować od spraw europejskich, czy włączyć się aktywnie do systemu zbiorowego bezpieczeństwa oferowanego przez Ligę Narodów? Zmiany na mapie politycznej Europy, a zwłaszcza w bezpośrednim sąsiedztwie, wokół Morza Bałtyckiego stanowiły dużą szansę, ale i poważne wyzwanie. Niemcy i Rosja osłabione w wyniku wojny i wewnętrznych zawirowań, po jej zakończeniu praktycznie wycofały się ze strefy bałtyckiej. Pojawiły się nowe państwa, słabe i niestabilne, ale stanowiące strefę oddzielająca Bałtyk od Rosji. W Sztokholmie zadawano sobie pytanie, czy właściwy będzie powrót do dawnej tradycji - XVIII- i XIX-wiecznej - obecności szwedzkiej w Finlandii, Estonii i na Łotwie. Czy może lepsza okaże się pozycja biernego obserwatora, spokojnie czekającego na samoistne ugruntowanie nowej sytuacji bądź na restytucję wpływów rosyjskich i niemieckich $\mathrm{w}$ - jak to określił Kristiansen w tytule swego przywoływanego wcześniej opracowania - „dalekiej i niebezpiecznej strefie bałtyckiej”. $\mathrm{Z}$ jednej strony witano zatem z zadowoleniem odepchnięcie Rosji od Bałtyku i wykształcenie nowej sytuacji strategicznej, zwiększającej bezpieczeństwo Szwecji, z drugiej obawiano się kłopotów powstałych poprzez utrudnienia $\mathrm{w}$ handlu ze wschodem i poważnych komplikacji $\mathrm{w}$ regionie $\mathrm{w}$ momencie ewentualnej zmiany koniunktury międzynarodowej ${ }^{6}$.

${ }^{1}$ Zob. prace Piotra Łossowskiego: Stosunki polsko-litewskie 1918-1920, Warszawa 1966; Po tej i tamtej stronie Niemna. Stosunki polsko-litewskie 1883-1939, Warszawa 1985; Konflikt polsko-litewski 1918-1920, Warszawa 1996.

2 S. Sierpowski, Liga Narodów w latach 1919-1926, Wrocław 2005, rozdz. 2, s. 85-103 (podrozdz. „Wileńszczyzna i sprawa Kłajpedy”).

${ }^{3}$ T. Kristiansen, Det fjerne och farlige Baltikum. Norge och det baltiske spørsmål 1918-1940, IFS Info, Nr 4, Institutt for forsvarsstudier, Oslo 1992.

${ }^{4}$ D. Faszcza, K. Faszcza, Przygotowania armii duńskiej do udziału w plebiscycie na terenie Wileńszczyzny w 1920 r., „Dzieje Najnowsze” R. XLIV, 2012, nr 1, s. 3-11.

${ }_{5}$ Temat ten zasygnalizował Adam Staniszewski w pracy Po dwóch stronach Battyku. Polityczno-gospodarcze stosunki polsko-szwedzkie w latach 1918-1932, Toruń 2013, s. 104-107.

${ }^{6}$ W.M. Carlgren, Sverige och Baltikum. Från mellankrigstid till efterkrigsår. En översikt, Stockholm 1993, s. 13. 
Ostatecznie rząd szwedzki postawił na ostrożna politykę, nie wchodząc $\mathrm{w}$ żadne konstelacje polityczne. Swoje zaangażowanie w krajach bałtyckich ograniczył do zezwolenia na prywatną wysyłkę broni oraz zaciag ochotniczy żołnierzy, którzy pragnęli wziąć udział w walkach w obronie niepodległości Finlandii i Estonii w 1918 r. ${ }^{7} \mathrm{~W}$ marcu 1920 r., po długotrwałych dyskusjach, podjęto ważną decyzję o wspólnym z innymi krajami skandynawskimi przystapieniu do Ligi Narodów. Jeszcze w tym samym roku rząd socjaldemokratyczny premiera Hjalmara Brantinga postanowił nawiązać oficjalne stosunki z państwami bałtyckimi, bo jak wytłumaczył minister spraw zagranicznych Erik Palmstierna: „Szwecja ma oczywisty interes, by takie buforowe państwa istniały". Ostatecznie Łotwę i Estonię uznał rząd liberalno-konserwatywny Louisa De Geera na początku lutego $1921 \mathrm{r}$. Uznanie Litwy de iure nastapiło najpóźniej, bo pod koniec września 1921 r. Zwłokę tłumaczono konfliktem polsko-litewskim. Poza tym trudno było zauważyć jakaśs większą aktywność dyplomatyczną Szwecji w regionie ${ }^{9}$. Wręcz przeciwnie, socjaldemokraci na czele z Brantingiem, którzy powrócili do władzy w październiku 1921 r., mimo wcześniejszych deklaracji o większym zaangażowaniu po wschodniej stronie Bałtyku, uznali, że „wiązanie się na śmierć i życie z nowymi państwami bałtyckimi niesie ze sobą szczególne niebezpieczeństwo" ${ }^{10}$. Okazując poparcie dla tych państw, wykluczano absolutnie „przejęcie za nie bezpośredniej odpowiedzialności politycznej lub militarnej”"11. Warto przypomnieć, że jednocześnie Szwecji ewidentnie zależało na odciagnięciu Finlandii od państw bałtyckich i Polski poprzez rozwinięcie w Helsinkach orientacji skandynawskiej i rezygnację z sojuszu z Warszawą ${ }^{12}$. Aktywna polityka na Bałtyku stawała się zreszta coraz mniej możliwa wraz z rozpoczęciem redukcji armii i floty, której kulminacja nastapiła w 1925 r.

Szwecja swą działalność na arenie międzynarodowej skupiła przede wszystkim w Lidze Narodów, gdzie reprezentowali ją najwyższej rangi

${ }^{7}$ L. Gyllenhaal, L. Westberg, Svenskar i krig 1914-1945, Lund 2004, s. 80-89. Wielka Brytania chciała wtedy skłonić kraje skandynawskie do większego zaangażowania w krajach bałtyckich i wysłania swych wojsk dla zabezpieczenia tego terenu przed bolszewikami. Rządy państw bałtyckich, zagrożone agresją ze wschodu, po wycofaniu się armii niemieckich i dążące do zbliżenia ze Skandynawia, daremnie oczekiwały pozytywnej reakcji rządów Szwecji, Danii i Norwegii. Zob. T. Kristiansen, op. cit., s. 9-12. Tu m.in. informacja o brytyjskiej propozycji wysłania przez Norwegię do „byłych rosyjskich prowincji bałtyckich” 2 tys. żołnierzy.

${ }^{8}$ W.M. Carlgren, op. cit., s. 16.

${ }_{9}$ Ibidem, s. 17. Zob. też: U. Larsson, Svensk socialdemokrati och Baltikum under mellankrigstiden, Stockholm 1996, s. 18-24.

10 Sprawozdanie roczne rządu dla komisji spraw zagranicznych z 15 I 1922 r. Cyt. za: W.M. Carlgren, op. cit., s. 18.

${ }^{11}$ Ibidem.

${ }^{12}$ K. Kangeris, Die schwedische Baltikumpolitik 1918-1925. Ein Überblick, in: The Baltic in International Relations between the Two World Wars, ed. J. Hiden, A. Loit, „Acta Universitatis Stockholmiensis. Studia Baltica Stockholmiensia” (Uppsala) 1988, vol. III, s. 199-200. 
politycy. Nawet sprawę przyszłości Wysp Alandzkich, o których przynależność państwową prowadziła spór z Finlandia, oddała do rozstrzygnięcia w ręce organów Ligi. Rząd w Sztokholmie był przekonany, że społeczność międzynarodowa, w ogólnych założeniach bezstronna i sprawiedliwa, miała jedynie potwierdzić, że zdecydowana większość ludności archipelagu, należącego do zakończenia I wojny światowej do Rosji, była szwedzka i dlatego roszczenia Szwecji okazały się jak najbardziej uzasadnione. Można stwierdzić, że kraje skandynawskie przygotowywały się od lat do uczestnictwa w Lidze Narodów, promując traktaty arbitrażowe i procedury koncyliacyjne w stosunkach międzynarodowych. Same wytworzyły powszechne przekonanie, że sa powołane do misji szerzenia pokoju na świecie ${ }^{13}$. Dlatego po przystapieniu do Ligi Szwecja pragnęła odegrać aktywną w niej rolę. Dążyła do ograniczenia roli wielkich mocarstw na rzecz mniejszych państw, tak by prawo dominowało nad siła, a sprawiedliwość nad realizacją celów politycznych. Krótko mówiąc, rządy prawa miały zastapić koncert mocarstw, a idea arbitrażu i koncyliacji poddana odpolityzowaniu ${ }^{14}$. Trzeba $\mathrm{w}$ tym miejscu podkreślić, że Szwedzi przejawiali inklinację do ścisłego trzymania się litery prawa. Kierownicy polityki zagranicznej z niewielkimi wyjątkami byli profesorami prawa, sędziami i adwokatami ${ }^{15}$. Generalnie panowała też opinia, że „Justice through the rule of law has long been deeply ingrained in the mentality of the Northern folk” (,Sprawiedliwość osiagnięta drogą prawna jest głęboko zakorzeniona w mentalności narodów północnych" ${ }^{16}$. Dlatego Skandynawom zależało na podniesieniu znaczenia instrumentów prawnych w działaniach Ligi. Tu napotykali opór zwycięskich mocarstw kładacych nacisk na polityczny charakter Ligi ${ }^{17}$. Przeciwnicy aspirowania do przywództwa politycznego na Bałtyku w szwedzkim Ministerstwie Spraw Zagranicznych niekiedy starali się przeciwdziałać nawet koncepcji odgrywania prominentnej roli w Lidze Narodów. Podsumowując swą misję szefa Wydziału Politycznego-Handlowego Utrikesdepartementet (czyli szwedzkiego MSZ, w skrócie UD), Torvald Höjer sporządził w 1923 r. memorandum o szwedzkiej polityce zagranicznej, w którym odrzucał przypisaną Szwecji rolę „błędnego rycerza prawa międzynarodowego" ${ }^{18}$. To pełne rezerwy, często nawet kunktatorskie podejście do zagadnień międzynarodowych musiało wpływać na interpretację konfliktu o Wilno i ewentualnego udziału Szwecji w jego rozwiązaniu.

${ }^{13}$ S. Shepard Jones, The Scandinavian States and the League of Nations, New York 1939, s. 22-25, 30-36.

${ }^{14}$ Ibidem, s. 153, 176, 183, 191; E. Lönnroth, Den svenska utrikespolitikens historia, vol. V: 1919-1939, Stockholm 1959, s. 37.

${ }_{15}$ Podkreśla to E. Lönnroth, op. cit., s. 23.

${ }^{16}$ S. Shephard Jones, op. cit., s. 39.

${ }^{17}$ Ibidem, s. 59.

${ }^{18}$ L. Torbjörn Norman, „A Foreign Policy Other than the Old Neutrality” Aspects of Swedish Foreign Policy after the First World War, in: The Baltic in International Relations..., s. 247. 
Echa sporu polsko-litewskiego zaczęły docierać do szwedzkiej opinii publicznej już pod koniec I wojny światowej. Działalność propagandowa na rzecz niepodległości Litwy rozwiną wtedy w prasie szwedzkiej Ignas Jurkunas-Scheynius. W swych artykułach przekonywał, że połączenie Polaków i Litwinów w jednym państwie odbędzie się ze szkodą dla tych drugich. Uważał bowiem, że interesy „konserwatywnej oligarchicznej arystokracji” w Polsce i „radyklanej demokratycznej inteligencji” na Litwie rozmijają się zupełnie. Dla niego było oczywiste, że polskie oferty współpracy „to tylko ładne słowa”, wszak Polacy chcieli wcielić Litwę do wspólnej unii. Dlatego państwa zachodnie - uważał - powinny pomóc Litwinom, w przeciwnym razie „polscy imperialiści ujarzmią naród litewski”. Scheynius podawał przykład Szwedów i Norwegów, którzy po rozwiązaniu unii ułożyli wzajemne stosunki w poprawny sposób i zgodnie ze sobą współpracują ${ }^{19}$. W miarę upływu czasu litewskie wypowiedzi zwrócone przeciwko Polsce stały się jeszcze bardziej napastliwe. W lutym 1920 r. na łamach poczytnego dziennika liberalnego „Dagens Nyheter” ukazał się artykuł pod znamiennym tytułem: Polskie marzenia imperialne. Jak walka przeciw Sowietom stworzy Wielka Polskę. Anonimowy „korespondent z Kowna” zaatakował Polskę za „agresywny imperializm" i traktowanie Litwy jak naturalnego terenu dla swej ekspan$\mathrm{sji}^{20}$. Artykuł spotkał się z protestem Gustawa Simona z Warszawy, który przebywał akurat w Sztokholmie dla przestudiowania szwedzkiego ruchu spółdzielczego. Simon przekonywał, że w korespondencji z Kowna pojawiły się „niezgodne z prawdą twierdzenia”, bo Polska wysłała swoje wojsko na wschód nie w celach imperialnych, lecz dla obrony własnej suwerenności. Uznał, że takie wypowiedzi są przykładem siania niezgody między Polakami a narodami, które wyzwoliły się spod rosyjskiego ucisku.

$\mathrm{Na}$ szczeblu dyplomatycznym Szwedzi zainteresowali się konfliktem polsko-litewskim na początku września 1920 r., po akcji zaczepnej wojsk litewskich na południowej Suwalszczyźnie i zwróceniu się ministra spraw zagranicznych Polski Eustachego Sapiehy do Ligi Narodów o pomoc i interwencję ${ }^{21}$. W związku z tym, że Szwecja nie utrzymywała stosunków dyplomatycznych z Litwa, jesienią 1920 r. głównym źródłem informacji Sztokholmu o stanie stosunków polsko-litewskich był poseł szwedzki w Warszawie, Cossva Anckarsvärd. Po wydarzeniach w okolicach Suwałk wyjaśniał on ministrowi spraw zagranicznych swego kraju, że początek konfliktu polsko-litewskiego oraz niedawnych walk na pograniczu i w ich efekcie apel rządu polskiego do Ligi Narodów trzeba datować znacznie wcześniej. Już bowiem 8 XII 1919 r.

\footnotetext{
${ }^{19}$ I. Jurkunas-Scheynius, Litauisk-polska förhållanden, [cz.] 1, „Stockholms Dagblad”, 14 I 1918; idem, Litauisk-polska förhållanden, [cz.] 2, „Stockholms Dagblad”, 18 I 1918.

${ }^{20}$ Polska imperiedrömmar. Hur striden mot Sovjet skulle skapa Stor Polen, „Dagens Nyheter”, 23 II 1920.

${ }^{21}$ P. Łossowski, Po tej i tamtej stronie Niemna..., s. 142.
} 
Rada Najwyższa ustaliła granicę prowizoryczną według linii dawnej granicy Królestwa Kongresowego na północ od Suwałk (tzw. linia Focha). Kiedy doszło do odwrotu wojsk polskich na wschód, Litwini podpisali 12 VII 1920 r. układ o przyszłej granicy z władzami sowieckimi, w którym zapewnili przejęcie Wilna w swoje posiadanie. Jednak wkrótce, po zwycięstwie w bitwie warszawskiej, Polacy powrócili na sporne terytorium. Według Anckarsvärda „w kręgach Ententy uważa się, że Polacy maja pełną rację". Z informacji, jakie uzyskał w Warszawie, wynikało, że strona polska chciała za wszelka cenę uniknąć starcia zbrojnego z Litwą („Wojna z Litwą byłaby nadzwyczaj nie na rękę dla Polski, gdy mają się rozpoczaćc rokowania pokojowe z bolszewikami”). Nie chodziło o obawy przed armia litewska, bo ta była słaba (cała ludność litewska liczyła $2 \mathrm{mln}$ ). A i ze strony Litwinów widziano bojowa postawę tylko w kręgach wojskowych. Dyplomaci alianccy twierdzili, że dużą rolę w polityce litewskiej odgrywali zarówno Sowieci, jak i Niemcy. Sam Anckarsvärd uważał, że wojna nie jest w interesie żadnego z „siostrzanych narodów”, ale spór uznał za trudny do rozwiązania w sytuacji, gdy Wilno zamieszkiwała ludność polska i trudno było oczekiwać, że zagłosuje ona za Litwa. Szwedzki dyplomata nie rozumiał polityki litewskiej, bo - jak pisał w swym raporcie do Sztokholmu - Litwa, kontynuując współpracę z Rosją Sowiecka, ryzykowała, że zostanie przez nią wchłonięta. Natomiast mogłaby się oprzeć na Polsce, która na pewno prędzej będzie dbać o jej interesy. Anckarsvärd wykluczył prowadzenie przez Litwę samodzielnej polityki, bo uważał ją za zbyt słabe państwo ${ }^{22}$.

Od 30 IX 1920 r. w Suwałkach toczyły się rokowania polsko-litewskie w sprawie ustalenia przyszłej granicy między obu państwami. 4 października na miejsce obrad przybyła Komisja Kontrolna Ligi Narodów z płk. Pierre'em Chardigny na czele. Pod jej wpływem doszło do porozumienia i podpisania umowy 7 października. Z ustalonej umową suwalską linii demarkacyjnej wynikało, że Wilno pozostanie po stronie litewskiej. Dla dyplomacji litewskiej umowa ta stała się głównym atutem, który dowodził praw Litwy do Wilna ${ }^{23}$. Jak wiadomo, 9 października doszło do przesilenia w sprawie wileńskiej. Generał Lucjan Żeligowski z polecenia Józefa Piłsudskiego zają Wilno i przystapił do organizowania administracji kraju zwanego Litwą Środkową ${ }^{24}$. Dwa dni później Anckarsvärd donosił o tych wydarzeniach do Sztokholmu: „Niespodziewanie, ale niezupełnie nie do przewidzenia - pisał szwedzki poseł - wojska polskie, złożone z Polaków z Litwy i Białorusi, pod dowództwem gen. Żeligowskiego, pod koniec ubiegłego tygodnia rozpoczęy okupacje Wilna, którego większość z 200 tysięcy mieszkańców to Polacy”. Za organem

\footnotetext{
${ }^{22}$ Riksarkivet (dalej: RA), Utrikesdepartemetet (dalej: UD), 1920 års dossiersystem, HP 32, vol. 1463, C. Anckarsvärd do E. Palmstierny, Warszawa, 6.09.1920.

${ }^{23}$ P. Łossowski, Po tej i tamtej stronie Niemna..., s. 156-159.

${ }^{24}$ Szerzej zob. ibidem, s. 160-169.
} 
rządu polskiego „Journal de Pologne” Szwed podał informację, że akcja była wynikiem buntu i nastapiła wbrew woli władz w Warszawie ${ }^{25}$. W piśmie do placówek dyplomatycznych Höjer wysuną przypuszczenie, że mimo doniesień Anckarsvärda, iż Żeligowski przeprowadził akcję na własną odpowiedzialność, trudno uwierzyć w niewiedzę rządu polskiego o tych zamiarach. Szwedzka dyplomacja od początku dostrzegała kontekst ogólnoeuropejski całej sprawy, stanowiącej „cios wymierzony w Ligę Narodów”26.

Anckarsvärd starał się dowiedzieć od różnych dyplomatów jak najwięcej o istocie sporu polsko-litewskiego i przekazać te wiadomości do centrali. Według niego był to „konflikt między braćmi, którzy maja interes w tym, by się jak najszybciej pojednać". Za główna przyczynę niepowodzenia prób porozumienia od początku uważał intrygi obcych państw. 14 października pisał do Sztokholmu, że rząd w Kownie pozostawał pod wpływem reprezentantów Niemiec i Rosji Sowieckiej. Z zainteresowaniem przyjmował propozycje francuskie, zbliżone do koncepcji federacyjnych Piłsudskiego, by połączyć Litwę i Białoruś z Polską i zapewnić im autonomię ${ }^{27}$. Ostatecznie 28 października Rada Ligi Narodów podjęła decyzję o przeprowadzeniu plebiscytu na spornym terenie, gdzie walki trwały aż do umowy rozejmowej z 29 XI $1920 \mathrm{r}$.

W drugiej połowie listopada okazało się, że Szwecja może zostać zaangażowana w spór polsko-litewski w charakterze rozjemcy. Sekretarz generalny Ligi Narodów James Eric Drummond wystosował pismo do delegata Szwecji do Zgromadzenia Ligi Narodów Brantinga ${ }^{28}$. W piśmie tym zaproponował szwedzkie uczestnictwo w ekspedycji „niedużych sił wojskowych dla zabezpieczenia plebiscytu na obszarze spornym między Litwą i Polską". W wyprawie miały uczestniczyć także oddziały belgijskie, brytyjskie, hiszpańskie i francuskie, być może greckie i włoskie. Drummondowi zależało na uczestnictwie Szwecji, nie tylko, by wzmocnić siły ekspedycyjne, ale i by „pokazać, że trudne zadanie Ligi Narodów ma pełne poparcie u innych rządów i że Rada może liczyć na ich pomoc". Wielka Brytania, Francja i Hiszpania już miały zadeklarować wysłanie po 300 żołnierzy, a Belgia - 100. Szwedzki kontyngent, podobnie jak belgijski, dysponował 100-osobowa kompania. Ponadto strona szwedzka miała oddać do dyspozycji komisji plebiscytowej $4-5$ oficerów znających język polski lub rosyjski i posiadających doświadczenie w sprawach administracyjnych. Drummond zaznaczył, że wszelkie wydatki „ponad normalne koszty utrzymania oddziałów" (specjalny żołd, transport) zostaną zwrócone krajom wysyłającym wojsko z budżetu Ligi Narodów. Wydatki te miały być zrekompensowane Lidze Narodów przez Polskę i Litwę, proporcjonalnie do wyników

\footnotetext{
${ }^{25}$ RA, UD 1920 års dossiersystem, HP 32, vol. 1463, C. Anckarsvärd do UD, Warszawa, 11.10.1920.

${ }^{26}$ Ibidem, T. Höjer do szwedzkich placówek dyplomatycznych, Sztokholm, 13.10.1920.

${ }^{27}$ Ibidem, C. Anckarsvärd do UD, Warszawa, 14.10.1920.

${ }^{28}$ Ibidem, E. Drummond do H. Brantinga, 21.11.1920.
} 
plebiscytu. Termin wysłania oddziałów był bliski, dlatego Drummond dodał, że oddział może dołaczyć do ekspedycji z opóźnieniem. Podobna propozycję przesłano rządom Holandii, Danii i Norwegiii ${ }^{29}$.

Członkowie szwedzkiej reprezentacji w Genewie byli zdania, że nie należało się uchylać od spełnienia zaproponowanego przez Drummonda zadania. Erik Marks von Würtemberg (sędzia Sądu Najwyższego Szwecji, minister spraw zagranicznych w latach 1923-1924) i Erik Trygger (parlamentarzysta, premier w latach 1923-1924, następnie minister spraw zagranicznych w latach 1928-1930) we wspólnym telegramie powiązali sprawę kontyngentu ze staraniami Szwecji o miejsce w Radzie Ligi Narodów. Stwierdzili, że odmowa udziału zapewne zaszkodzi szwedzkim widokom na uczestnictwo w Radzie. Jednocześnie konsultowano się z innymi państwami zainteresowanymi sprawa udziału w ekspedycji. Okazało się, że pozostałe kraje skandynawskie były nastawione pozytywnie, przy czym Norwegowie zaznaczyli, że wyślą wyłącznie ochotników, a Duńczycy - tylko personel cywilny ${ }^{30}$. Ostatecznie rządy Szwecji, Danii i Norwegii zgadzały się co do wysłania kontyngentu wojskowego o podobnej liczebności, złożonego z ochotników. Wszystkie też chciały uzyskać akceptację własnych parlamentów ${ }^{31}$. W Szwecji decydująca okazała się opinia parlamentarnej komisji spraw zagranicznych. Wszędzie interpretowano cała sprawę w kategoriach prestiżu i własnej pozycji w Lidze ${ }^{32}$. Być może Szwedzi myśleli też o oddanej do decyzji Ligi Narodów przyszłości Wysp Alandzkich, licząc na większą przychylność mocarstw. Na pewno znaczenie miała stosunkowo niewielka liczba żołnierzy, o którą prosił Drummond. W pamięci wciąż pozostawała brytyjska prośba z 1918 r. o przygotowanie kontyngentu sięgającego kilku tysięcy rekrutów.

Na przełomie listopada i grudnia 1920 r. na łamach dziennika „Social-Demokraten" ukazały się pozytywne komentarze na temat idei plebiscytu i szwedzkiego w nim współudziału (26 i 27 XI oraz 10 XII). W prawicowych dziennikach było inaczej, ale to tłumaczyć można ich negatywnym nastawieniem do Ligi Narodów w ogólności ${ }^{33}$. Dla socjaldemokratów poparcie dla działań międzynarodowej organizacji pilnującej przestrzegania prawa stanowiło logiczna konsekwencję dotychczasowej polityki.

Już 26 XI 1920 r. od posła szwedzkiego w Christianii (dzisiaj Oslo) przyszła wiadomość, że władze norweskie, mimo głosów przeciwnych zarówno ze strony polityków prawicowych, jak i socjaldemokratycznych, poprą uczestnictwo

${ }^{29}$ Ibidem.

${ }^{30}$ Ibidem, Pro memoria dotyczące propozycji Rady Ligi Narodów wysłania szwedzkiego kontyngentu wojskowego na polsko-litewski obszar plebiscytowy, Sztokholm, 24.11.1920; ibidem, W. Boström do C.G. Hammarskjölda (Ministerstwo Obrony), Sztokholm, 29.11.1920.

${ }^{31}$ Ibidem, F. Ramel do premiera de Geera, Christiania, 29.11.1920.

${ }^{32}$ T. Kristiansen, op. cit., s. 18.

${ }^{33}$ U. Larsson, op. cit., s. 25. 
w ekspedycji ${ }^{34}$. Następnego dnia z UD rozesłano do szwedzkich placówek dyplomatycznych pismo, w którym podkreślono, że to, o co prosi Liga Narodów, „nie należy do obowiązków jej członków”35. Jednocześnie objaśniono, że „członek Ligi Narodów nie powinien unikać współpracy w sprawie, która oznacza ochronę pokoju i ładu międzynarodowego - a to przecież powód, dla którego Szwecja uczestniczy w Lidze Narodów i nie może zawieść w takim przypadku". W ten sposób uzasadniono pozytywną decyzję w tej sprawie. Dodano też, że aktywność oddziału szwedzkiego ograniczy się do obszaru plebiscytowego i nie ma widoków na to, że potrzebne będzie użycie broni, ponieważ do czasu plebiscytu inne wojsko, oprócz kontyngentu międzynarodowego, tam się nie pojawi. Zdaniem kierownictwa szwedzkiej dyplomacji nieduża liczebność oddziałów plebiscytowych wskazywała, że chodziło wyłącznie o zabezpieczenie głosowania, nie o akcję zbrojna. Po konsultacji z królem Gustawem V ustalono, że Szwecja przyjmie propozycję Ligi Narodów i zgodnie z ta prośbą wyśle do Wilna 100 żołnierzy oraz dodatkowo kilku oficerów.

Decyzja Szwecji zrobiła w Sekretariacie Ligi Narodów bardzo dobre wrażenie, tym bardziej że - jak relacjonował sekretarz delegacji szwedzkiej przy Lidze Narodów Carl Hamilton - „nasz list nie zawierał żadnych warunków” ${ }^{36}$. Ta reakcja w Genewie potwierdzała szwedzkie nadzieje na uzyskanie niestałego członkostwa w Radzie Ligi Narodów. Sprawa kontyngentu mogła zwiększyć szanse Szwecji popieranej przez Wielką Brytanię i jednocześnie zredukować szanse konkurentów, zwłaszcza Czechosłowacji, której stronę trzymała Francja. Oczywiście ważne było też podjęcie starań o głosy innych państw - przede wszystkim chodziło o Amerykę Łacińska.

Tymczasem po doniesieniach prasowych o przygotowywanej ekspedycji, do UD zaczęli zgłaszać się rezerwiści w charakterze ochotników ${ }^{37}$. Jednak w pierwszej kolejności bazowano na żołnierzach służby czynnej z pułku Svea Livgarde, stacjonującego w Sztokholmie. Datę końcową rekrutacji ustalono na 5 grudnia, o czym powiadomiono komunikatem na łamach dziennika „Svenska Dagbladet” 1 grudnia ${ }^{38}$. Formalnie dzień wcześniej - 30 XI 1920 r. - zaczęło się formowanie „oddziału wileńskiego” (Vilna detachementet), kiedy Gustaw V wystosował pismo w tej sprawie do dowództwa armii ${ }^{39}$. Wskazał $\mathrm{w}$ nim, że powinna to być kompania piechoty postawiona w stan gotowości bojowej, podległa królowi, a administracyjnie - dowódcy 4 Dywizji Piechoty. Wyodrębniono też grupę kilku oficerów, którzy mieli być oddelegowani do

\footnotetext{
${ }^{34}$ RA, UD 1920 års dossiersystem, HP 32, vol. 1463, F. Ramel do T. Höjera, Christiania, 26.11.1920.

${ }^{35}$ Ibidem, UD do szwedzkich placówek dyplomatycznych, Sztokholm, 27.11.1920.

${ }^{36}$ Ibidem, C. Hamilton do T. Höjera, Genewa, 29.11.1920.

${ }^{37}$ Ibidem, Karta pocztowa dwóch piechurów, obecnie woźnych w hotelu (E. Björkman i E. Johansson) do UD, Kalmar, 30.11.1920.

${ }^{38}$ Ibidem, I. Danielsson (UD) do E. Björkmana [zob. przypis 34], 1.12.1920.

${ }^{39}$ Ibidem, Król Gustaw V do Dowództwa Armii, 30.11.1920.
} 
Komisji Plebiscytowej. Mimo że oficjalnie podkreślano pokojowy charakter misji, wszystkim żołnierzom winno zostać zapewnione wynagrodzenie czasu wojny ze specjalnymi dodatkami. Poza tym zaplanowano specjalne wydatki na wyposażenie w postaci czterech motocykli, auta i map Wileńszczyzny.

Kontynuowano zbieranie informacji o terenie Szwedom niemal zupełnie nieznanym. W prasie szwedzkiej pojawiły się reportaże o Wilnie i oddziale, który miał być tam wysłany ${ }^{40}$. $\mathrm{Z}$ doniesień posłów z różnych stolic europejskich wynikało, że plebiscyt będzie formalnościa, bo większość ludności na obszarze spornym to Polacy, a ponadto Białorusini i Żydzi. Litwini stanowili natomiast mniejszość. Frapujące było stanowisko polskie wobec państwa litewskiego. Polscy dyplomaci w rozmowach ze Szwedami podkreślali, że pragną dobrosąsiedzkich stosunków z niepodległą Litwą w granicach etnograficznych. Według nich nie było to możliwe ze względu na wpływy niemieckie i sowieckie w tym kraju. Nie mieli natomiast wątpliwości, że wynik plebiscytu okaże się pomyślny dla strony polskiej ${ }^{41}$. Zreszta w końcu listopada, w obawie przed konsekwencjami politycznymi odrzucenia uchwały Rady Ligi Narodów, ideę plebiscytu poparły zgodnie rządy Polski, Litwy oraz gen. Żeligowski. Ustalono nawet wstępnie datę głosowania na 31 I lub 1 II $1921 \mathrm{r}$. Sytuacja na miejscu wydawała się niepewna i nieustabilizowana, bo przypuszczano, że akcję ofensywną moga przygotowywać bolszewicy. Do tego dochodziły plotki o planach Żeligowskiego marszu dalej na Kowno ${ }^{42}$.

Skandynawowie nastawili się na jak najgorsze warunki sanitarne i zaplanowali obowiązkowe szczepienie żołnierzy przeciwko ospie i tyfusowi ${ }^{43}$. Ponadto przygotowano szczepionki przeciwko cholerze, dyfterytowi i tężcowi oraz środki dezynfekujące przeciwko wszom. Dowództwo postanowiło, by w momencie wyjazdu wyposażyć kontyngent w żywność na jeden miesiąc ${ }^{44}$. Na początku grudnia był już gotowy skład osobowy i wyposażenie nowo uformowanej jednostki, stanowiący wynik zarówno oczekiwań Ligi Narodów, jak i koordynacji działań UD, dowództwa armii szwedzkiej i wymiany informacji z dyplomatami duńskimi i norweskimi ${ }^{45}$. Ostatecznie oddział tworzył kompanię złożoną ze 100 żołnierzy pod dowództwem kpt. Sköldebranda. W skład kompanii wchodziło: 3 oficerów, adiutant kompanijny, 5 podoficerów, 3 sanitariuszy, ekipa telefoniczna, 2 ordynansów na motocyklach, oficer intendentury, 2 lekarzy. Kompania dzieliła się na 3 plutony, przy czym jeden z nich wyposażono

${ }^{40}$ Vilna, son får svensk ordningshjälp, „Göteborgs Handels- och Sjöfarts Tidning”, 4 XII 1920; Den svenska Vilnatruppen, „Upsala Nya Tidning”, 10 XII 1920; Ett och annat från Vilna, „Upsala Nya Tidning”, 10 XII 1920.

${ }^{41}$ RA, UD 1920 års dossiersystem, HP 32, vol. 1463, Notatka: Wypowiedź posła polskiego w Kopenhadze o Wilnie i stosunku Polski do Litwy, 30.11.1920.

${ }^{42}$ Ibidem, C. Anckarsvärd do UD, Warszawa, 25.11.1920.

${ }^{43}$ Ibidem, J. Beck-Friis do UD, Kopenhaga, 1.12.1920.

${ }^{44}$ Ibidem, vol. 1464, T. Höjer do F. Ramela i J. Beck-Friisa, Sztokholm, 22.12.1920.

${ }^{45}$ Ibidem, vol. 1463, Pro memoria, Sztokholm, 3.12.1920. 
w 2 ciężkie karabiny maszynowe, dwa kolejne - w 2 karabiny maszynowe „Madsen”. W grupce oficerów dodatkowo przydzielonych do kontyngentu (na życzenie Ligi Narodów) znaleźli się: ppłk Landegren, mjr Herslow, kpt. Uggla, rotmistrz Rappe. Skład osobowy ekspedycji uzupełniało 4 ordynansów (2 na motocyklach, maszynista oraz szofer). Na potrzeby oddziału oddano auto i kuchnię polową. Każdy żołnierz otrzymał specjalny dodatek pieniężny, bezpłatny wikt i opierunek, opiekę zdrowotna ${ }^{46}$.

Wystarczyło tylko poczekać na akceptację wyprawy przez parlament. 2 XII 1920 r. wysłanie ekspedycji przegłosowano w parlamencie norweskim ${ }^{47}$. Dzień później propozycja rządu duńskiego w tej samej sprawie trafiła do Folketingu, gdzie posłowie w dyskusji przed pomyślnym dla rządu głosowaniem zaznaczyli, że musi to być akcja policyjna i żołnierze kontyngentu nie powinni się mieszać w walki między Polakami i Litwinami ${ }^{48}$.

Kiedy wszystkie formalności natury prawnej zostały sfinalizowane, a oddziały były przygotowane do wyjazdu, rozpoczęło się organizowanie transportu. Liga Narodów zaproponowała, by kontyngenty państw skandynawskich połaczyć i zorganizować jeden transport droga morska. Swoje usługi rządowi szwedzkiemu zaoferowało przedsiębiorstwo „Sveabolaget”, proponując transport do Gdańska, przy czym statek wypłynąłby 15 grudnia, a przybył na miejsce trzy dni później - 18 grudnia ${ }^{49}$. Szwedzi uznali to rozwiązanie za najpraktyczniejsze, w dodatku stosunkowo tanie, dlatego tę propozycję przedłożyli w Genewie. Takie postawienie sprawy czyniło projekt wspólnej podróży z Duńczykami i Norwegami za niemożliwy do realizacji. Statek był bowiem za mały. Poza tym w Norwegii właśnie zaczął się strajk kolejarzy, co oznaczało, że żołnierze tamtejszego kontyngentu nie mogli przyjechać pociagiem do Sztokholmu. Pozostawał im jedynie rejs statkiem przez Kopenhagę. Ewentualnie ze stolicy Danii żołnierze norwescy i duńscy mogli podróżować razem ${ }^{50}$. Ostatecznie okazało się, że i Duńczycy, i Norwegowie woleli zorganizować transport na własną rękę. Norweskie dowództwo chciało wysłać swój oddział wynajętym statkiem z Christianii bezpośrednio do Gdańska ${ }^{51}$. Minister spraw zagranicznych Danii Scavenius natomiast poinformował Szwedów, że ich kontyngent popłynie własnym okrętem wojennym. Zaznaczył równocześnie, że woli poczekać na wyklarowanie sytuacji, bo na razie plebiscyt był wciąż niepewny ze względu na sprzeciwy władz Litwy

\footnotetext{
${ }^{46}$ Por. A. Staniszewski, op. cit., s. 105.

${ }^{47}$ Ibidem, F. Ramel do premiera De Geera, Christiania, 2.12.1920. Przeciwko zagłosowało 18 posłów socjaldemokratycznych.

${ }^{48}$ Ibidem, J. Beck-Friis do UD, Kopenhaga, 3.12.1920 oraz 9.12.1920. Zob. też: Udsendelsen til Vilna, „Politiken”, 4 XII 1920.

${ }^{49}$ RA, UD 1920 års dossiersystem, HP 32, vol. 1463, Sveabolaget do UD, Sztokholm, 7.12.1920. Statek „Egil” najpierw miał zawinąć do Libawy, następnie kontynuować rejs do Gdańska.

${ }^{50}$ Ibidem, W. Boström (UD) do posłów Szwecji w Christianii i Kopenhadze, 7.12.1920.

${ }^{51}$ Ibidem, F. Ramel do premiera i UD, Christiania, 9.12.1920.
} 
Środkowej. Stanowisko to potwierdził premier Danii Niels Neergaard ${ }^{52}$. Poza tym z Warszawy dochodziły też wieści o stale aktualnych szansach na realizację programu federacyjnego, co plebiscyt czyniłoby bezprzedmiotowym ${ }^{53}$. Jednocześnie inne źródła zaprzeczały temu, twierdząc, że Litwa „orientuje się na Niemcy" i nie ma dużych widoków na odprężenie w stosunkach z Polska ${ }^{54}$. Minister Sapieha zapewniał Anckarsvärda, że w istocie rząd polski opowiada się za rozwiązaniem federacyjnym, chociaż nie jest $\mathrm{w}$ stanie zebrać większości sejmowej za tym projektem, a Polacy z Wileńszczyzny również go nie popierają. Plebiscyt uważał za złe rozwiązanie, bo nie miał wątpliwości, że wynik pozytywny dla strony polskiej tylko pogłębi orientowanie się Litwy na Niemcy, natomiast zwycięstwo Litwinów w głosowaniu wzbudzi duże niezadowolenie ludności polskiej i zaogni stosunki dwustronne z Litwa. Dlatego w nadziei na porozumienie w sprawie federacji rząd polski chciał odroczenia terminu plebiscytu ${ }^{55}$. Stopniowo pojawiały się obiekcje ze strony Litwinów. Zaczęli oni mianowicie twierdzić, że w świetle ich układu z Rosją Sowiecką z 12 VII 1920 r. żadne obce wojsko nie mogło wejść na ich terytorium ${ }^{56}$. Nagle, w finalnej fazie przygotowań do wysłania kontyngentu międzynarodowego do Wilna, ekspedycja stanęła pod znakiem zapytania. Dodatkowo niepokój wzbudziły zapewne doniesienia o koncentracji wojsk bolszewickich w sąsiedztwie Wileńszczyzny ${ }^{57}$. Duńczycy nie zrażali się tymi komunikatami. W połowie grudnia oddział duński był przygotowany i miał zostać poddany szczepieniom. W związku z tym, że okres dochodzenia do pełnej sprawności po przyjęciu szczepień trwał ok. 15 dni, oddział powinien wyruszyć w podróż za trzy tygodnie ${ }^{58}$. Duńczycy zadbali nawet o opiekę duszpasterską dla żołnierzy i pomyśleli o dołączeniu do kontyngentu pastora A.V. Storma. Zaproponowali partnerom szwedzkim i norweskim, by Storm spełniał rolę kapelana dla wszystkich oddziałów skandynawskich ${ }^{59}$. Oddział norweski miał być przygotowany do podróży najpóźniej do końca roku. Ostatecznie po skoordynowaniu daty gotowości oddziałów do wyjazdu, Skandynawowie wysłali do Genewy deklarację, że wojsko najwcześniej zostanie wysłane 29 grudnia $^{60}$.

${ }^{52}$ Ibidem, J. Beck-Friis do UD, Kopenhaga, 9.12.1920; ibidem, T. Höjer do płk. O. Nygrena (Dowództwo Armii), Sztokholm, 11.12.1920.

${ }^{53}$ Ibidem, T. Höjer do posłów Szwecji w Christianii (Ramel) i Kopenhadze (Beck-Friis), Sztokholm, 11.12.1920.

${ }^{54}$ Ibidem, Pro memoria J. Lagerberga (UD), Sztokholm, 9.12.1920. Cennym źródłem informacji okazał się Szwed kpt. Melin, służący w armii łotewskiej.

${ }^{55}$ Ibidem, C. Anckarsvärd do UD, Warszawa, 8.12.1920.

${ }^{56}$ Ibidem, Attaché wojskowy Szwecji w Warszawie mjr Lovén: Pro memoria z rozmowy z płk. P. Chardigny, 10.12.1920.

${ }^{57}$ Ibidem, vol. 1464, Konsul szwedzki w Tallinie Torsten Undén do UD, Tallin, 20.12.1920.

${ }^{58}$ Ibidem, T. Höjer do C.G. Hammarskjölda, Sztokholm, 16.12.1920.

${ }^{59}$ Ibidem, Poselstwo duńskie w Sztokholmie do UD, Sztokholm, 17.12.1920.

${ }^{60}$ Ibidem, T. Höjer do F. Ramela i J. Beck-Friisa, Sztokholm, 22.12.1920. 
Tymczasem minister spraw zagranicznych Norwegii Christian Fredrik Michelet w rozmowie z posłem szwedzkim w Christianii Fredrikiem Ramelem 21 grudnia już dobitniej zaznaczył, że „jest bardzo sceptyczny” co do wyjazdu wojsk skandynawskich do Wilna, „przynajmniej w najbliższym czasie”, z powodu, jak się wyraził, „niespokojnych stosunków, jakie tam panują”. W każdym razie zadeklarował, że Norwegowie nie wyruszą bez porozumienia ze Sztokholmem i Kopenhaga ${ }^{61}$. Wiadomo już było, że Rada Ligi Narodów wciąż czeka na odpowiednie deklaracje od władz polskich i litewskich w sprawie plebiscytu. Od pozytywnych odpowiedzi z Warszawy i Kowna uzależnione było przybycie kontyngentu międzynarodowego na obszar plebiscytowy ${ }^{62}$.

Doniesienia z kolejnych dni nie były zachęcające. Konsul szwedzki w Tallinie Torsten Undén usłyszał od dyplomaty litewskiego, że „w ogóle nie będzie plebiscytu na Wileńszczyźnie”. Rząd litewski brał bowiem pod uwagę stanowisko Rosji Sowieckiej, a ta chciała Litwę za sąsiada. Wygrana Polski w plebiscycie uniemożliwiłaby takie rozwiązanie. Dyplomacja sowiecka już 11 grudnia w czasie rokowań pokojowych z delegacja polską zgłosiła sprzeciw wobec zajęcia Wilna przez Żeligowskiego oraz wobec pomysłu przysłania obcych wojsk w związku z plebiscytem. W oczach bolszewików obecność sił międzynarodowych mogła być przygotowaniem do działań antysowieckich ${ }^{63}$. Litwini, krótko mówiąc, liczyli na dalszą presję ze strony Sowietów oraz mediację brytyjska, co mogło doprowadzić do przyznania Wilna Litwie ${ }^{64}$. Idei plebiscytu sprzeciwiała się Rosja Sowiecka, co oczywiście musiało wpłynąć na negatywne nastawienie Litwy. Poza tym Żeligowski nie zgadzał się na wycofanie swoich wojsk ${ }^{65}$.

Początkowo większym optymistą był Anckarsvärd, który uspokajał, że bolszewicy próbowali destabilizować sytuację, ale tak naprawdę nie mieli żadnych podstaw, by mieszać się w sprawę przyszłości Wilna. Natomiast Chardigny zapewniał, że jak tylko zapadnie decyzja o przeprowadzeniu plebiscytu, Żeligowski wycofa się z Wilna ${ }^{66}$. Ton raportów Anckarsvärda zmienił się po Nowym Roku. Na początku stycznia napisał, że rozmowy polsko-litewskie zostały zawieszone, bo każda ze stron przystępowała do nich z odmiennymi oczekiwaniami. Litwini kładli nacisk na kwestię granicy, a Polacy chcieli rozmawiać o przyszłych powiązaniach politycznych i gospodar-

${ }^{61}$ Ibidem, F. Ramel do UD, Christiania, 21.12.1920.

${ }^{62}$ Ibidem, Eric Drummond do UD, Genewa, 23.12.1920.

${ }^{63}$ Ibidem, Pro memoria dotyczące stanowiska rządu sowieckiego wobec idei plebiscytu na Wileńszczyźnie (brak podpisu, brak daty). Zob. też: R. Žiugžda, Lithuania in International Relations in the 1920's, in: The Baltic in International Relations..., s. 65.

${ }^{64}$ RA, UD 1920 års dossiersystem, HP 32, vol. 1464, Konsul szwedzki w Tallinie Torsten Undén do UD, Tallin, 3.01.1921.

${ }^{65}$ R. Žiugžda, op. cit., s. 65.

${ }^{66}$ RA, UD 1920 års dossiersystem, HP 32, vol. 1464, C. Anckarsvärd do UD, Warszawa, 20.12.1920. 
czych $^{67}$. Tak naprawdę relacje polsko-litewskie weszły w „okres chroniczny”. Granice z Wilnem po stronie polskiej mocarstwa zachodnie uznały w marcu 1923 r., a dwustronne stosunki dyplomatyczne zostały nawiąane dopiero w 1938 r., w zupełnie innych realiach i sytuacji międzynarodowej68.

$\mathrm{W}$ związku z zawieszeniem decyzji o plebiscycie $\mathrm{w}$ następnych dniach rozpoczął się proces rozformowywania szwedzkiego oddziału „wileńskiego”. Minister obrony Carl Gustaf Hammarskjöld polecił dowódcy 4 Dywizji odesłać żołnierzy do swych macierzystych jednostek, ewentualnie do innych oddziałów albo po prostu urlopować. Nie przesądzano jeszcze sprawy zrezygnowania $\mathrm{z}$ realizacji misji rozjemczej w Wilnie, bo żołnierze mieli oczekiwać na dalsze decyzje, w tym także na możliwy powrót do oddziału „wileńskiego"69. 18 lutego Anckarsvärd pisał o „najgłębszym pesymizmie” Chardigny w sprawie plebiscytu. Okazało się, że Polacy nie wycofają się z Wilna i co za tym idzie, nie zostana spełnione wymogi, jakie Liga Narodów stawiała idei plebiscytu. Co prawda, 4 lutego premier Wincenty Witos zapewnił w Genewie, że wojska Żeligowskiego zostaną wycofane w dniu, w którym przybędą do Wilna oddziały plebiscytowe i administracja kontrolna Ligi Narodów ${ }^{70}$, ale członkowie komisji międzynarodowej nie wierzyli już w szczerość polskich intencji. Demobilizację wojsk Żeligowskiego uznano za pozorna ${ }^{71}$. W końcu w UD w specjalnym memorandum wypunktowano kilka zdarzeń, które oznaczały w istocie koniec projektu. Podkreślono, że Szwajcaria odmówiła przepuszczenia przez swoje terytorium oddziałów francuskich, brytyjskich, belgijskich i hiszpańskich, bo jak stwierdzono, kłóciłoby się to z neutralnościa Konfederacji Szwajcarskiej. Ponadto w tym czasie w formie mnożących się warunków wstępnych ujawniła się otwarta litewska niechęć do planu przeprowadzenia plebiscytu. Litwini zaczęli domagać się natychmiastowego wycofania wojsk Żeligowskiego, zaprowadzenia administracji plebiscytowej i zagwarantowania, że Polacy nie ponowia próby siłowego rozwiązania sporu w razie przegranej w plebiscycie. Żądali też uznania swego państwa de iure. Poza tym Litwini forsowali tezę, że ich układ z Rosja Sowiecka z lipca 1920 r. właściwie zadecydował już o przynależności Wilna do Litwy ${ }^{72}$. Nie bez znaczenia dla pogłębiających się

${ }^{67}$ Ibidem, C. Anckarsvärd do UD, Warszawa, 6.01.1921.

${ }^{68} \mathrm{O}$ tym szerzej zob. P. Łossowski, Ultimatum polskie do Litwy 17 marca 1938 roku. Studium z dziejów dyplomacji, Warszawa 2010.

${ }^{69}$ RA, UD 1920 års dossiersystem, HP 32, vol. 1464, K.G. Hammarskjöld do dowódcy 4 Dywizji, Sztokholm, 21.01.1921. W sumie ze 121 oficerów i żołnierzy 24 I 1921 r. urlopowano 44 , do innych jednostek wysłano 38, do macierzystych jednostek odesłano 6, w służbie pozostawiono 30. Jeden rekrut zrezygnował i odszedł do cywila.

${ }^{70}$ Ibidem, Pro memoria dotyczące stanowiska Litwy wobec idei plebiscytu na Wileńszczyźnie (brak podpisu, brak daty).

${ }^{71}$ Ibidem, Anckarsvärd do Wrangla, Warszawa, 18.02.1921.

${ }^{72}$ Ibidem, Pro memoria dotyczące stanowiska Litwy wobec idei plebiscytu na Wileńszczyźnie (brak podpisu, brak daty). Swoje żądania Litwa sformułowała w liście do Ligi Narodów datowanym na 28 I 1921 r. Zob. też: ibidem: obszerne, 24-stronicowe Pro memoria 
wątpliwości co do sensu przygotowań plebiscytowych w Skandynawii było zwłaszcza niejasne stanowisko Sowietów, a także, podobna do szwajcarskiej, niechęć przyłączenia się do akcji okazywana przez Hiszpanów ${ }^{73}$. Rząd polski próbował zneutralizować obawy przed kontrakcją ze strony sowieckiej, zapewniajacc, że w traktacie pokojowym (a rozmowy ryskie były już finalizowane) Rosja miała się zobowiązać do akceptacji obecności sił międzynarodowych na Wileńszczyźnie. Po tych zapewnieniach Liga Narodów wyznaczyła datę przybycia kontyngentu na 10 marca $^{74}$. Jednocześnie okazało się, że administracja wileńska nie została $\mathrm{w}$ ogóle przygotowana na przyjęcie żołnierzy sił międzynarodowych. Pod koniec lutego Anckarsvärd dowiedział się, że koszary dla kontyngentu będa gotowe „najwcześniej za miesiąc”75. W prasie europejskiej zaczęły się pojawiać doniesienia o odwołaniu plebiscytu. 4 III 1921 r. poseł szwedzki w Paryżu Johan Ehrensvärd potwierdził te spekulacje, pisząc, że w związku ze sprzeciwami Litwy oraz polską odmową wycofania wojsk Żeligowskiego z Wilna Rada Ligi Narodów już 2 marca podjęła decyzję o rezygnacji z plebiscytu i postawiła na rokowania dwustronne w Brukseli pod patronatem Paula Hymansa w celu rozstrzygnięcia problemów - nie tylko terytorialnych, ale też politycznych i gospodarczych. To rozwiązanie rzecz jasna oznaczało, że żadne siły międzynarodowe nie zostaną wysłane do Wilna ${ }^{76}$. Dalsze rokowania polsko-litewskie, zresztą bezowocne, miały się toczyć w Brukseli pod przewodnictwem Hymansa i stałym nadzorem Rady Ligi Narodów ${ }^{77}$. Ostatecznie w dniu 11 marca Gustaw V wystosował do dowództwa armii pismo, w którym wskazał, że oddział „wileński” powinien zostać rozwiązany do 31 marca, a wszyscy żołnierze mają otrzymać propozycje stałego zatrudnienia $\mathrm{w}$ wojsku ${ }^{78}$. Nie był to jednak koniec historii wyprawy „wileńskiej”.

Skandynawowie zaczęli domagać się od Ligi Narodów zwrotu kosztów organizacji niedoszłej do skutku ekspedycji. Najpierw sprawę poruszył poseł duński w Bernie Andreas de Oldenburg, który spotkał się z Drummondem. Przewodniczący Ligi Narodów potraktował Duńczyka chłodno. Stwierdził tylko, że nie zna sprawy i odesłał Oldenburga do dyrektora Sekcji Politycznej Ligi Narodów Paula Mantoux i dyrektora Sekcji Prawnej Joosta van Hamela. Żaden

dotyczące sprawy wileńskiej, 28.02.1921, gdzie mowa o zarzutach szwajcarskich, że nie określono jasno zasad plebiscytu i braku jedności obu stron zainteresowanych w sprawie przeprowadzenia głosowania.

${ }^{73}$ Ibidem, Notatka UD (podpis nieczytelny), 25.02.1921.

${ }^{74}$ Ibidem, T. Höjer do duńskiego MSZ, Sztokholm, 1.03.1921.

${ }^{75}$ Ibidem, T. Höjer do posłów J. Beck-Friisa (Kopenhaga) i F. Ramela (Christiania), Sztokholm, 28.02.1921.

${ }^{76}$ Ibidem, Notatka UD (podpis nieczytelny), 4.03.1921 oraz Notatka UD, 9.03.1921.

77 P. Łossowski, Stosunki polsko-litewskie 1921-1939, Warszawa 1997, s. 12-23; S. Sierpowski, op. cit., s. 91-96.

${ }^{78}$ RA, UD 1920 års dossiersystem, HP 32, vol. 1465, K.G. Hammarskjöld i O. Nygren: Pro memoria, 11.03.1920. 
z kolejnych rozmówców duńskiego dyplomaty nie wypowiadał się pozytywnie o roszczeniach skandynawskich. Wyjaśniali oni, że zobowiazanie Rady do pokrycia kosztów ekspedycji można interpretować na różne sposoby, ale przede wszystkim zarzucili, że rządy Szwecji i Danii nie informowały o potrzebie z ich strony specjalnego organizowania kontyngentu i formowania odrębnych jednostek wojskowych. Poza tym wystapił problem podziału kosztów między Polskę i Litwę w sytuacji, gdy nie doszło do plebiscytu, a przecież jego wynik miał być podstawa do odpowiednich obliczeń. Na pewno na pełne rezerwy stanowisko Sekretariatu Ligi Narodów wpływała zła sytuacja finansowa organizacji. Rada Ligi rozpatrzyła sprawę dopiero 12 V 1922 r. Na spotkanie zaproszono zarówno Oldenburga, jak i posła szwedzkiego w Bernie Patricka Adlercreutza, którzy zaprezentowali punkt widzenia swoich rządów, przy czym Szwed na razie nie przedstawił konkretnej sumy roszczenia. Hymans bronił się, że Rada zakładała, iż kontyngenty będą się składać z żołnierzy służby czynnej każdego państwa-uczestnika. Dlatego liczono się wyłącznie z kosztami transportu wojska do Wilna i utrzymania na miejscu w okresie plebiscytu. Nie brano pod uwagę kosztów związanych z werbunkiem. Kwotę ponad 44 tys. koron żądanych przez Danię Hymans określił jako „wyjątkowo wysoką" Inaczej do problemu podszedł przewodniczący Rady Ligi Narodów (poza tym prezydent Senatu francuskiego i laureat Pokojowej Nagrody Nobla z 1920 r.) Léon Bourgeois, który podkreślił moralne znaczenie zaangażowania się państw skandynawskich w pierwszą tego typu akcję. Uważał, że Liga Narodów powinna przede wszystkim wyrazić wdzięczność i nie tworzyć precedensów w postaci niespełnienia prośby o zwrot kosztów. Według relacji Adlercreutza to wystapienie zrobiło na członkach Rady duże wrażenie i okazało się decydujące. Następny z mówców, lord Arthur Balfour podsumował, że skoro Rada obiecała pokryć „wszystkie dodatkowe koszty”, to niezależnie od interpretacji tego zapisu przez rządy Szwecji i Danii należało dotrzymać słowa. Sprawa była zatem załatwiona. Roszczenia Szwecji i Danii uznano za uprawnione. Postanowiono, że zwrot kosztów nastapi w 1923 r. Pozostał jednak problem odzyskania tych kwot od Litwy i Polski ${ }^{79}$. Natomiast Szwecja do jesiennej sesji Rady Ligi Narodów miała dokonać szczegółowych obliczeń i przedstawić kwotę, jaka chciała odzyskać.

Adlercreutz zwrócił uwagę, że sprawa Wilna obnażyła pewne niedostatki armii szwedzkiej. Dopiero w fazie przygotowań do wyprawy zaczęto myśleć o zmianie zasad odbywania służby wojskowej, ponieważ te zakazywały wysyłania poborowych za granicę. Okazało się, że zapis ten kłócił się z członkostwem Szwecji w Lidze Narodów. Adlercreutz zaapelował o przyspieszenie zmiany w tym zakresie, aby jesienia w Genewie nie pojawiły się zarzuty stawiajace Szwecję w złym świetle. Przed obliczeniem kosztów zorganizowania kontyngentu zaproponował, by zorientować się, jakie koszty poniosły

${ }^{79}$ Ibidem, vol. 1467, P. Adlercreutz do H. Brantinga, Berno, 13.05.1922. 
państwa okupujące Niemcy po zakończeniu wojny oraz Dania w związku z plebiscytem w Szlezwiku. W tym miejscu powołał się na Oldenburga, który na pytanie w tej kwestii odpowiedział, że jego rząd „wydał miliony” Branting list Adlercreutza skwitował tylko podziękowaniem za „skuteczna reprezentację" interesów szwedzkich w Radzie Ligi Narodów ${ }^{81}$. W Sztokholmie spodziewano się „krytycznego rozpatrzenia” wysokości roszczeń szwedzkich za względu na usilne poszukiwanie oszczędności w budżecie Ligi. Urzędnicy UD byli świadomi, że zwłaszcza wysokość poborów otrzymanych przez żołnierzy mogła wzbudzić wątpliwości w Genewie. Dlatego zbierano informacje o wydatkach na wojsko na różnych obszarach plebiscytowych, tak by uzyskać jak najmocniejsze uzasadnienie dla własnych żądań ${ }^{82}$. W październiku na III Zgromadzeniu Ligi Narodów zapadła w końcu decyzja o uznaniu roszczeń trzech krajów skandynawskich i przyznano im tytułem zwrotu 422260 franków szwajcarskich w złocie ${ }^{83}$. Udział Szwecji po przeliczeniu wyniósł 147895 koron i 97 öre, o czym dyrektor finansowy Sekretariatu Ligi Narodów Herbert B. Amis poinformował ministra sprawa zagranicznych Szwecji pismem z 26 X 1922 r. ${ }^{84} \mathrm{~W}$ przypadku Norwegii sprawa przedłużyła się do $1924 \mathrm{r}$. Dopiero wtedy, po szczegółowych wyliczeniach, z których wynikało, że poniesiono koszty w wysokości ok. 211500 koron, reprezentanci Norwegii przedstawili prośbę o zwrot 56 tys. koron. Postanowiono starać się tylko o zwrot części kwoty ze względu na niedojście do skutku ekspedycji, a zatem na fakt, że „wydatki trzeba uważać za pieniądze wyrzucone w błoto" ${ }^{55}$.

Sprawa wileńska zeszła na dalszy plan w działalności polityków i dyplomatów szwedzkich. Po wydarzeniach 1920 r. mieli o niej ugruntowane zdanie i niezależnie od przychylnego Polsce stanowiska posłów szwedzkich rezydujących w Warszawie, centrala w Sztokholmie konsekwentnie, przynajmniej w latach dwudziestych, brała stronę litewska. Kiedy w 1924 r. poseł RP Alfred Wysocki rozpoczynał swa kilkuletnią misję dyplomatyczną w Sztokholmie, z zaskoczeniem przyjął wypowiedzi swych szwedzkich partnerów na temat Wilna. Minister spraw zagranicznych Marks von Würtemberg „powrót Wilna do naszej macierzy nazywał niebezpiecznym precedensem, gen. Żeligowskiego żołnierzem, który powinien stanaćc przed sądem" ${ }^{86}$. Również premier Branting napiętnował zajęcie Wilna, mówiąc Wysockiemu, że Żeligowskiego „należało

${ }^{80}$ Ibidem, P. Adlercreutz do T. Höjera, Berno, 15.05.1922.

${ }^{81}$ Ibidem, H. Branting do P. Adlercreutza, Sztokholm, 24.05.1922.

${ }^{82}$ Ibidem, E. Boheman (UD) do Poselstwa Szwecji w Kopenhadze, Sztokholm, 16.08.1922.

${ }^{83}$ Ibidem, Notatka UD, 24.10.1922.

${ }^{84}$ Ibidem, Herbert B. Amis do ministra spraw zagranicznych Szwecji, Genewa, 26.10.1922. Zob. też: A. Staniszewski, op. cit., s. 107.

${ }^{85}$ RA, UD 1920 års dossiersystem, HP 32, vol. 1467, Poselstwo Szwecji w Christianii do UD, Christiania, 5.04.1924. Zob. też: T. Kristiansen, op. cit., s. 23.

${ }^{86}$ A. Wysocki, Na placówce dyplomatycznej w Sztokholmie 1924-1928. Wspomnienia, wybór, oprac. i przedm. P. Jaworski, Toruń 2004, s. 21. 
natychmiast postawić pod sąd wojenny i dla przykładu najsurowiej ukarać"87. Ale od spraw bałtyckich Szwecja trzymała się z daleka. Szwedom zależało jedynie na przyciagnięciu do krajów skandynawskich Finlandii ${ }^{88}$. Ich horyzont polityczny na południe od Zatoki Fińskiej nie sięgał.

Trudno oczywiście stwierdzić, jak bardzo zaangażowanie w przygotowania wyprawy wileńskiej wzmocniło rolę krajów skandynawskich w Lidze Narodów. W każdym razie sprawę Wysp Alandzkich załatwiono nie po myśli Szwecji, bo ostatecznie 24 VI 1921 r. Rada Ligi Narodów ogłosiła rezolucję uznająca władzę Finlandii na obszarze archipelagu. Rząd szwedzki zaakceptował decyzję Rady, chociaż Branting pozwolił sobie na kilka cierpkich uwag, wskazując na niewłaściwość rozwiązania, a nawet sprzeczność z zasadami, na jakich miała się opierać działalność Ligi ${ }^{89}$. Jednocześnie trzeba pamiętać, że po rozszerzeniu Rady Ligi Narodów do sześciu miejsc, w styczniu 1923 r. Szwecja weszła do tego grona i „mogła efektywniej forsować szwedzki punkt widzenia na zagadnienia wielkiej polityki, które wymagały decyzji Rady". Jej rola w Lidze Narodów rzeczywiście wzrosła. Przez kilka kolejnych lat premier Branting był czołowa postacia organizacji. Swymi wystapieniami zyskał autorytet i opinię niezłomnego obrońcy słabszych państw w oparciu o literę prawa międzynarodowego ${ }^{90}$.

Szwecja jeszcze raz zgodziła się wysłać swój kontyngent na obszar plebiscytowy w Europie. W 1935 r., kiedy organizowano referendum w Zagłębiu Saary, obok wojsk brytyjskich, włoskich i holenderskich, znalazły się oddziały szwedzkie w liczbie 250 żołnierzy. I tym razem rekrutowano ochotników, bo w konstytucji szwedzkiej nadal widniał zapis o zakazie wysyłania wojska poza granice kraju ${ }^{91}$. Nie wiadomo, jak załatwiono sprawę pokrycia kosztów zorganizowania wyprawy.

\section{Streszczenie}

Spór polsko-litewski o Wileńszczyznę w latach 1918-1923 ma już bogatą literaturę, gdzie objaśnia się kompleksowo problemy związane z tym zagadnieniem, w tym genezę konfliktu. Znane jest też zaangażowanie Ligi Narodów w całą sprawę, łącznie z propozycją przeprowadzenia na spornym obszarze plebiscytu pod ochrona sił międzynarodowych. Słabo poznany wątek stanowi natomiast kwestia organizacji oddziałów z różnych krajów, które miały wziąć udział w (ostatecznie niedoszłej do skutku) wyprawie do Wilna. Celem niniejszego tekstu jest zaprezentowanie problemu ze szwedzkiej perspektywy, z uwzględnieniem celów polityki zagranicznej neutralnej Szwecji, jej aktywności w Lidze Narodów oraz stosunku do sytuacji po drugiej stronie Bałtyku. Spór polsko-litewski obserwowano w Sztokholmie z uwaga, ale nie angażowano się w jego rozwiązanie. Dopiero w listopadzie 1920 r. Liga Narodów zwróciła się

\footnotetext{
${ }^{87}$ Ibidem, s. 39.

${ }^{88}$ E. Lönnroth, op. cit., s. 76.

89 S. Sierpowski, op. cit., s. 83-84.

${ }^{90}$ E. Lönnroth, op. cit., s. 40-46.

${ }^{91}$ S. Shepard Jones, op. cit., s. 269-270.
} 
m.in. do Szwecji o wysłanie do Wilna oddziału wojskowego, który miałby zabezpieczyć obszar planowanego plebiscytu. Rząd szwedzki przyją tę misję, podobnie, jak kilka innych państw, w tym Dania i Norwegia. Sprawę interpretowano w kategoriach prestiżu i własnej pozycji w Lidze. W efekcie zorganizowano specjalna, 100-osobową jednostkę wojskową (liczebnie podobną do oddziałów duńskiego i norweskiego), która, po akceptacji parlamentu, przygotowano pod względem technicznym do wyprawy na pogranicze polsko-litewskie. Zaplanowano rejs statkiem do Gdańska, potem przejazd stamtąd do Wilna. Jednak w marcu 1921 r. okazało się, że do plebiscytu nie dojdzie, bo Polska i Litwa nie osiagnęły porozumienia co do warunków, w jakich miałoby się odbyć głosowanie. Szwedzki oddział, nazywany „wileńskim”, rozformowano. Wtedy zaczęły się żmudne rozmowy między dyplomatami skandynawskimi a Sekretariatem Ligi Narodów w sprawie zwrotu kosztów organizacji niedoszłej do skutku ekspedycji. W końcu część roszczeń państw skandynawskich uwzględniono. Rola Szwecji w Lidze Narodów wzrosła, co mogło być w pewnym stopniu związane z zaangażowaniem w przygotowania wyprawy do Wilna.

\section{Swedish “Vilnius" force - unrealised mediatory expedition in 1920/1921}

A Polish-Lithuanian conflict over the Vilnius region in 1918-1923 has a rich literature, explaining comprehensively problems related to this issue, including the origins of the strife. And the involvement of the League of Nations is well-known, including the proposal to conduct in the disputed area a plebiscite under the protection of international forces. There is one question, however, insufficiently researched, that is the problem of those military units from different countries which were to organise the planned (and finally unrealised) expedition to Vilnius. The purpose of the article is to present the problem as seen from the Swedish perspective, with due regard to foreign policy aims of neutral Sweden, its activity in the League of Nations, and its attitude towards the situation on the other side of the Baltic Sea. The Polish-Lithuanian conflict was carefully observed from Stockholm, but without any Swedish engagement in it. Only in November of 1920 the League of Nations asked Sweden, among other countries, to send to Vilnius a military unit to protect the planned plebiscite area. The Swedish government accepted the mission, like several other states, including Denmark and Norway. The matter was interpreted in categories of prestige and own Swedish position within the League. In response, a 100-member strong (like the Danish and Norwegian ones) Swedish military unit was organised which, after being accepted by the Parliament, was technically prepared to be sent to the Polish-Lithuanian border. According to the plan, the unit was to be shipped to Gdańsk, and then had to go to Vilnius. In March 1921, however, it turned out that the plans of the plebiscite were abandoned due to the lack of understanding between Poland and Lithuania as to the plebiscite conditions. The Swedish unit, called the Vilnius Force, was disbanded, and strenuous talks began between the Scandinavian diplomats and the LN Secretariat over a reimbursement from the League for the organisation of the unrealised expedition. In the end, a part of the claim of the Scandinavian states was accepted. The role of Sweden in the League of Nations increased, which could have resulted from the Swedish involvement in the preparation of the Vilnius expedition.

\section{Bibliografia}

Carlgren W.M., Sverige och Baltikum. Från mellankrigstid till efterkrigsår. En översikt, Stockholm 1993.

Faszcza D., Faszcza K., Przygotowania armii duńskiej do udziału w plebiscycie na terenie Wileńszczyzny w 1920 r., „Dzieje Najnowsze” R. XLIV, 2012, nr 1. 
Gyllenhaal L., Westberg L., Svenskar i krig 1914-1945, Lund 2004.

Kangeris K., Die schwedische Baltikumpolitik 1918-1925. Ein Überblick, in: The Baltic in International Relations between the Two World Wars, ed. J. Hiden, A. Loit, „Acta Universitatis Stockholmiensis. Studia Baltica Stockholmiensia” (Uppsala) 1988, vol. III.

Kristiansen T., Det fjerne och farlige Baltikum. Norge och det baltiske spørsmål 1918-1940, IFS Info, Nr 4, Institutt for forsvarsstudier, Oslo 1992.

Larsson U., Svensk socialdemokrati och Baltikum under mellankrigstiden, Stockholm 1996. Lönnroth E., Den svenska utrikespolitikens historia, vol. V: 1919-1939, Stockholm 1959.

Łossowski P., Konflikt polsko-litewski 1918-1920, Warszawa 1996.

Łossowski P., Po tej i tamtej stronie Niemna. Stosunki polsko-litewskie 1883-1939, Warszawa 1985.

Łossowski P., Stosunki polsko-litewskie 1918-1920, Warszawa 1966.

Łossowski P., Stosunki polsko-litewskie 1921-1939, Warszawa 1997.

Łossowski P., Ultimatum polskie do Litwy 17 marca 1938 roku. Studium z dziejów dyplomacji, Warszawa 2010.

Shepard Jones S., The Scandinavian States and the League of Nations, New York 1939.

Sierpowski S., Liga Narodów w latach 1919-1926, Wrocław 2005.

Staniszewski A., Po dwóch stronach Battyku. Polityczno-gospodarcze stosunki polsko-szwedzkie w latach 1918-1932, Torun 2013.

Torbjörn Norman L., „A Foreign Policy Other than the Old Neutrality” Aspects of Swedish Foreign Policy after the First World War, in: The Baltic in International Relations between the Two World Wars, ed. J. Hiden, A. Loit, „Acta Universitatis Stockholmiensis. Studia Baltica Stockholmiensia" (Uppsala) 1988, vol. III.

Wysocki A., Na placówce dyplomatycznej w Sztokholmie 1924-1928. Wspomnienia, wybór, oprac. i przedm. P. Jaworski, Torun 2004.

Žiugžda R., Lithuania in International Relations in the 1920's, in: The Baltic in International Relations between the Two World Wars, ed. J. Hiden, A. Loit, „Acta Universitatis Stockholmiensis. Studia Baltica Stockholmiensia” (Uppsala) 1988, vol. III.

Bi og r a m: Pawel Jaworski - dr hab., prof. Uniwersytetu Wrocławskiego, historyk specjalizujący się w historii Polski i powszechnej XIX i XX w., historii Skandynawii oraz Europy Środkowo-Wschodniej; najważniejsze publikacje: Polska niepodlegta wobec Skandynawii 1918-1939, Wrocław 2001; Między przymusowa przyjaźniq a prawdziwa solidarnościq. Czesi, Polacy, Stowacy 1938/39-1945-1989, cz. 1-2, Warszawa 2007-2009 (red. wraz z Łukaszem Kamińskim i Petrem Blažkiem); Marzyciele i oportuniści. Stosunki polsko-szwedzkie w latach 1939-1945, Warszawa 2009; Świat wobec „Solidarności” 1980-1989, Warszawa 2013 (red. wraz z Łukaszem Kamińskim); Most przez Battyk. Szwecja wobec „Solidarności” 1980-1982, Warszawa 2017. E-mail: pawel.jaworski@uwr.edu.pl. 